Path. Microbiol. 1968;31:380-384

\title{
Index rerum ad Vol. 31
}

Buchbesp $\Gamma$ echungen - Livres nouveaux - Book reviews $(\mathrm{V})=$ Vortrag - Communication Report

Acinetobacter anitratus, Biochemical Similarity of Acinetobacter Гwoffii and, 41

Acinetobacter lwoffii and Acinetobacter anitratus, Biochemical Similarity of, 41

Adenovirus Type 12 in Cultured Cells, Ultrastructural Study of the Replication of Human, 147

Africa, Ticks of the Genus Ixodes in, 188 (B)

Aging and Osteoarthrotic Human Cartilage, Electron Microscopic Investigations on, 14

Aktinomyzeten und verwandte Er-reger, Krankheiten durch, 251 (B)

Alloantigène cellulaire de la souris, Demonstration par immunofluo-rescence indirecte d'un, 345

Amyloid and Meduallary Carcinoma of the Thyroid. Electron Microscope Observations on One

Case, 93

Amyloidosis and the Effect of Cortisone Treatment, Experimental, 85

Antibiotics, Biosynthesis of, 190 (B)

Antibiotisch wirksame Substanzen bei Arbutus unedo L. (Erdbeer-strauch), Über, 243

Antibodies to Rat Tissue Antigens in the Rat, Patterns of Naturally Occurring Circulating, 1

Antigens in the Rat, Patterns of Naturally Occurring Circulating Antibodies to Rat Tissue, 1

Antikörperproduktion beim Hamster, Wirkung der Thymusexstirpation auf Blutbild und, 65

Arbutus unedo L. (Erdbeerstrauch), Über antibiotisch wirksame Substanzen bei, 243

Atypical Mycobacteria for Guinea-Pigs, The Pathogenicity of, 193

Atypical Mycobacteria, Intracerebral

Infection of Mice with M. avium

and, 287 Autoantikörper bei der Maus, Prä-

zipitierende Leber-, 257 Autoradiography, Techniques of,

64 (B)

Bactéries anaérobies, Les, 59 (B)

Bacteriophagy/Bakteriophagie 1957-1965, 255 (B)

Bakteriophagie/Bacteriophagy 1957-1965, 255 (B)

BALB/c-Maus induzierte trans-plantable Neoplasie (HIPA) mit plasmazellulärer Evolution,

Durch Milzhomogenat einer mit Mineral-öl behandelten. Zur Plasmozytom-Onkogenese (LPC-

1), 278

Biochemical Similarity of Acinetobacter lwoffii and Acinetobacter anitratus, 41

Biophysical and Histological Study, A Combined. Calcifications in the Prostate Gland and

Adjacent Tissues, 97

Biosynthesis of Antibiotics, 190 (B)

Blutbild und Antikörperproduktion beim Hamster, Wirkung der Thymusexstirpation auf, 65

Book Reviews, 59-64, 128, 187-191, 251-256

Buchbesprechungen 59-64, 128, 187-191, 251-256

Buffy Coat in Three-Dimensional Matrix Tissue Cultures and Mono-layers, Human, 353 
Calcifications in the Prostate Gland and Adjacent Tissues, A Combined Biophysical and Histological Study, 97

Cancer Incidence in Five Continents, 252 (B)

Index rerum ad Vol. 31

381

Cancerologie, Aktuelle Probleme aus dem Gebiet der, 128 (B)

Carcinoma of the Thyroid, Amyloid and Medullary. Electron Microscope Observations on One

Case, 93

Cardiac and Muscular Lesions in Mice and Rabbits Injected with Group A Streptococcal

Products, 233

Cartilage, Electron Microscopic Investigations on Aging and Osteoarthrotic Human, 14

Cartilage: The Effect of Acute Hyper-thyroidism, Electron Microscopy of Articular, 25 Chemie im medizinischen Laboratorium, 187 (B)

Circulating Antibodies to Rat Tissue Antigens in the Rat, Patterns of Naturally Occurring, 1

Citrobacter ballerup, Protéines communes des Salmonelles apparte-nant aux groupes B, C, D et

E, et leur relation avec. Contributions à Tétude des Salmonelles, 165

Colitis: A Negative Study, Myco-plasmas in Chronic Ulcerative, 209

Competence and Transformation in Streptococcus challis, Synthetic Medium for Development of, 226

Cortisone Treatment, Experimental $\chi \backslash$ myloidosis and the Effect of, 85

Desferrioxamine B sur la toxinogé-nèse diphtérique en milieu solide, Effet de la, 175

Diseases, Mediterranean and Tropical, Spezielle pathologische Anato-mie, Grundzüge einer historischen und geographischen Pathologie, 62 (B)

Electron Microscope Observations on One Case. Amyloid and Medullary Carcinoma of the Thyroid, 93

Electron Microscopic Investigations on Aging and Osteoarthrotic Human Cartilage, 14

Electron Microscopy of Articular Cartilage: The Effect of Acute Hyperthyroidism, 25

Electron-microscopic Findings in

the Spleen of Mice in Acute

Toxoplasmosis, 307 Elektronenmikroskopische Unter-

suchungen über das Glycogen im

Zellstoffwechsel, 60 (B) Enterobacteriaceae, Sur les détermi-

nats communs des, 321 Erdbeerstrauch, Über antibiotisch

wirksame Substanzen bei Arbutus

unedo L., 243 Experimentelle Pharmakologie,

Handbuch der, 63 (B)

Food Microbiology, Proceedings of the 5th International Symposium (Moscow, July 1966), 64

(B)

Forebrain of the Guinea Pig,

A Stereotaxic Atlas of the, 190 (B)

Genese aus menschlicher und tieri-scher Leber, Vergleichende Unter-suchungen an Lipofuscin verschie-dener, 108

Geographische Pathologie, Grundzüge einer historischen und. Mediterranean and Tropical

Diseases. Spezielle pathologische Anatomie, 62 (B)

Germinal Centers in Immune Responses, 254 (B) 
Glomerular Response in Human and Experimental Rickettsial Disease (Rocky Mountain Spotted Fever Group), 365

Glycogen im Zellstoffwechsel,

Elektronenmikroskopische Unter-suchungen über das, 60 (B)

Haemophilus parahaemolyticus, Identification d'un agent frequent: Sur Thémophilose du pore, 215

Hamster, Wirkung der Thymus-exstirpation auf Blutbild und Anti-körperproduktion beim, 65

Hémophilose du pore, Sur $\Gamma$. I. Identification d'un agent frequent: Haemophilus

parahaemolyticus, 215

Histochemie, Handbuch der, Band V. Lipide, 1. Teil, 61 (B)

Histochemie, Handbuch der, Band V. Lipide, 2. Teil, 61 (B)

382 Index re

Histological Study, A Combined Biophysical and. Calcifications in the Prostate Gland and

Adjacent Tissues, 97

Historische und geographische Pathologie, Grundzüge einer. Mediterranean and Tropical

Diseases. Spezielle pathologische Anatomie, 62 (B)

Human Adenovirus Type 12 in Cultured Cells, Ultrastructural Study of the Beplication of, 147

Hyperthyroidism, Electron Microscopy of Articular Cartilage: The Effect of Acute, 25

immune Responses, Germinal

Centers in, 254 (B) Immunobiological Standardization,

Symposia Series in, 254 (B) Immunofluorescence indirecte d'un

alloantigène cellulaire de la souris,

Demonstration par, 345 Infection of Mice with M. avium and

Atypical Mycobacíeria, Intra-

cerebral, 287 Intracerebral Infection of Mice with

M. avium and Atypical Myco-

bacteria, 287 Ixodes in Africa, Ticks of the Genus,

188 (B)

Kallusbildung, 251 (B)

Klinik medikamentöser Schäden des

Verdauungskanals, Pathologie

und,256 (B) Klinikopathologie, 251 (B) Krankheiten, Mykobakterien und

mykobakterielle, 256 (B)

Laboratorium, Chemie im medizini-schen, 187 (B)

Laboratory Methods in Microbiology, 63 (B)

Leber, Vergleichende Untersuchun-gen an Lipofuscin verschiedener Genese aus menschlicher und tierischer Leber, 108

Leber-Autoantikörper bei der Maus, Präzipitierende, 257

Leukocyte System of Rabbits

Receiving Repeated Injections of Staphylococcal Leukocidin, 328

ad Vol. 31

Lipofuscin verschiedener Genese aus menschlicher und tierischer Leber, Vergleichende

Untersuchungen an, 108

Liquor Cerebrospinalis, Symposium über den (Wien, 16. Jan. 1965), 191 (B)

Livres Nouveaux, 59-64, 128, 187-191, 251-256

M. avium and Atypical Mycobacteria, Intracerebral Infection of Mice with, 287 
Maus, Präzipitierende Leber-Autoantikörper bei der, 257

Medical Virology, Aspects of, 253 (B)

Mediterranean and Tropical Diseases. Spezielle pathologische Anatomie. Grundzüge einer historischen und geographischen Pathologie, 62 (B)

Mice with M. avium and Atypical Mycobacteria, Intracerebral Infection of, 287

Microbiology, Laboratory Methods in, 63 (B)

Microbiology, Proceedings of the 5th International Symposium on Food (Moscow, July 1966),

64 (B)

Molecular Biology of Viruses, The 253 (B)

Monolayers, Human Buffy Coat in Three-Dimensional Matrix Tissue Cultures and, 353

Morphogénèse et ultrastructure du virus fibromateux de Shope, 129

Muscular Lesions in Mice and Rabbits Injected with Group A Strepto-coccal Products, Cardiac and, 233

Mycobacteria for Guinea-pigs, The Pathogenicity of Atypical, 193

Mycobactéries, La résistivité élec-trique des suspensions de, 337

Mycoplasmas in Chronic Ulcerative Colitis: A Negative Study, 209

Mykobakterien und mykobakterielle Krankheiten, 256 (B)

Nahrung, Untersuchungen über die Beeinflussung des Wachstums der Ratte durch

Saccharosezusatz zur, 202

Index re

Naturally Occurring Circulating Antibodies to Rat Tissue Antigens in the Rat, Patterns of, 1

Neurovirulence of Viral Vaccines, International Symposium on, Proceedings of the 13th

Symposium organized by the Permanent Section of Microbiological Standardization (Munich,

August 25-28, 1965), 60 (B)

Onkogenese (LPC-1), Zur Plaso-zytom-. Durch Milzhomogenat einer mit Mineralöl behandelten

BALB/c-Maus induzierte trans-plantable Neoplasie (HIPA) mit plasmazellulärer Evolution, 278

Orthologie und Pathologie der Rückenmarksdurchblutung, Zur, 190 (B)

Osteoarthrotic Human Cartilage, Electron Microscopic Investigations on Aging and, 14

Pathogenicity of Atypical Myco-bacteria for Guinea-pigs, The, 193

Pathologie der Rückenmarksdurchblutung, Zur Orthologie und, 190 (B)

Pathologie, Grundzüge einer histori-schen und geographischen. Mediterranean and Tropical

Diseases. Spezielle pathologische Anatomie, 62 (B)

Pathologie, Handbuch der allgemei-nen, 187 (B)

Pathologie und Klinik medikamen-töser Schäden des Verdauungs-kanals, 256 (B)

Persorptions-Mechanismus, Beob-achtungen zum, 51

Pharmakologie, Handbuch der ex-perimentellen, 63 (B)

Physiology, Advances in Reproductive, 189 (B)

Plasmazelluläre Evolution, Durch Milzhomogenat einer mit Mineralöl behandelten BALB/c-

Maus induzierte transplantable Neoplasie (HIPA) mit. Zur Plasmozytom-Onkogenese (LPC-Í), 278

Plasmozytom-Onkogenese (LCP-1), Zur. Durch Milzhomogenat einer

rum ad Vol. 31

mit Mineralöl behandelten BALB/c-Maus induzierte transplantable Neoplasie (HIPA) mit

plasmazellulärer Evolution, 278

Pore, Sur Thémophilose du. I. Identification d'un agent frequent: Hae-mophilus

parahaemolyticus, 215 
PräzipitierendeLeber-Autoantikörper bei der Maus, 257

Prostate Gland and Adjacent Tissues, Calcifications in the. A Combined Biophysical and Histological Study, 97

Protéines communes des Salmonelles appartenant aux groupes B, C, D et E, et leur relation avec Citro-bacter ballerup. Contributions à $\Gamma$ étude des Salmonelles, 165

Rat Tissue Antigens in the Rat, Patterns of Naturally Occurring Circulating Antibodies to, 1 Ratte durch Saccharosezusatz zur Nahrung, Untersuchungen über die Beeinflussung des Wachstums der, 202

Replication of Human Adenovirus Typ 12 in Cultured Cells, Ultra-structural Stud\}' of the, 147 Reproductive Physiology, Advances in, 189 (B)

Résistivité électrique des suspensions de mycobactéries, La, 337

Rickettsial Disease (Rocky Mountain Spotted Fever Group), Glomerular Response in Human and Experimental, 365

(Rocky Mountain Spotted Fever Group), Glomerular Response in Human and Experimental Rickettsial Disease, 365

Saccharomyces cerevisiae, Der Sprossungszyklus von, 117

Saccharosezusatz zur Nahrung, Untersuchungen über die Beeinflussung des Wachstums der Ratte durch, 202

Salmonelles, Contributions à $\Gamma$ étude des. Protéines communes des Salmonelles appartenant aux groupes B, C, D et E, et leur relation avec Citrobacter ballerup, 165

384

Index rerum ad Vol. 31

Shope, Morphogénèse et ultrastruc-ture du virus fibromateux de, 129

Spleen of Mice in Acute Toxoplasmosis, Electron-microscopic Findings in the, 307

Standardization, Symposia Series in Immunobiological, 254 (B)

Staphylococcal Leukocidin, Leukocyte System of Rabbits Receiving Repeated Injections of, 328 Stereotaxic Atlas of the Forebrain of the Guinea-pig, A, 190 (B)

Streptococcal Products, Cardiac and Muscular Lesions in Mice and Rabbits Injected with Group A, 233

Streptococcus challis, Synthetic Medium for Development of Competence and Transformation in, 226

Synthetic Medium for Development of Competence and Transformation in Streptococcus challis, 226

Thymusexstirpation auf Blutbild und Antikörperproduktion beim Hamster, Wirkung der, 65 Thyroid, Amyloid and Medullary Carcinoma of the. Electron Microscope Observations on One Case, 93

Tissue Cultures and Monolayers, Human Buffy Coat in Three-Dimensional Matrix, 353

Toxinogénèse diphtérique en milieu solide, Effet de la desferrioxamine B sur la, 175

Toxoplasmosis, Electron-microscopic Findings in the Spleen of Mice in Acute, 307

Transformation in Streptococcus challis, Synthetic Medium for Development of Competence and, 226

Transmission of viruses by the water route, 252 (B)

Transplantable Neoplasie (HIPA) mit plasmazellulärer Evolution, Durch Milzhomogenat einer mit Mineralöl behandelten BALB/c-Maus induzierte. Zur Plasmo-zytom-Onkogenese (LPC-1), 278 
Tropical Diseases, Mediterranean and. Spezielle pathologische Ana-tomie. Grundzüge einer histori-schen und geographischen Patho-logie, 62 (B)

Ulcerative Colitis: A Negative Study, Mycoplasmas in Chronic, 209

Ultrastructural Study of the Replication of Human Adenovirus Type 12 in Cultured Cells, 147

Ultrastructure du virus fibromateux de Shope, Morphogénèse et, 129

Vaccines, International Symposium on Neurovirulence of Viral, Proceedings of the 13th

Symposium organized by the Permanent Section of Microbiological Standardization (Munich, August 25-28, 1965), 60 (B)

Verdauungskanal, Pathologie und Klinik medikamentöser Schäden des, 256 (B)

Viral Vaccines, International Symposium on Neurovirulence of, Proceedings of the 13th

Symposium organized by the Permanent Section of Microbiological Standardization (Munich, August 25-28, 1965), 60 (B)

Virology, Aspects of Medical, 253 (B)

Virus fibromateux de Shope, Morphogénèse et ultrastructure du, 129

Viruses by the water route, Transmission of, 252 (B)

Viruses, The Molecular Biology of, 253 (B)

Wachstums der Ratte durch Sac-charosezusatz zur Nahrung, Unter-suchungen über die

Beeinflussung des, 202

Zellstoffwechsel, Elektronenmikro-skopische Untersuchungen über das Glycogen im, 60 (B) 